Our Nature (2013), 11(1): 61-75

\title{
Food and Feeding Habits of the Mola Carplet Amblypharyngodon mola (Hamilton, 1822) in Rice Field Ecosystem with Consideration of Water Quality Parameters
}

\author{
Md. Mostafizur Rahman Mondol ${ }^{1 *}$, Dil Afroz Nahar ${ }^{1}$, Somen Dewan ${ }^{2}$, Md. \\ Mosaddequr Rahman ${ }^{1}$, Saleha Jasmine ${ }^{1}$, and Md. Yeamin Hossain ${ }^{1}$ \\ ${ }^{1}$ Department of Fisheries, Faculty of Agriculture, University of Rajshahi, Rajshahi - 6205, Bangladesh \\ ${ }^{2}$ Department of Fisheries Management, Faculty of Fisheries, Bangladesh Agricultural University, \\ Mymensingh - 2202, Bangladesh \\ *E-mail:mostafiz_bau@yahoo.com
}

Received: 30.03.2013, Accepted: 14.06.2013

\begin{abstract}
The present investigation was conducted in the Agronomy field laboratory of Bangladesh Agricultural University, Mymensingh, Bangladesh during May 1999 to August 1999 to reveal the food and feeding habits of Amblypharyngodon mola in the rice field ecosystem. Percentage of frequency of occurrence and percentage in number methods were used for the qualitative and quantitative estimation of plankton population. Results showed that, during the present study, the water quality parameters were within the suitable range for optimal fish growth and plankton population was abundant in the water of the rice plots. Gut content analysis of $A$. mola revealed a sum of 32 genera of phytoplankton belonging to Chlorophyceae (17), Euglenophyceae (2), Cyanophyceae (7) and Bacillariophyceae (6) and 8 genera of zooplankton under Rotifera (3), Cladocera (2) and Copepoda (3). In general, Navicula, Fragilaria, Chlorella, Chrysococcus, Closterium, Oscillatoria and Gomphosphaeria were found abundant both in the water of the rice plots and in the gut contents of $A$. mola indicating that, these genera are preferred food of this fish in the rice field ecosystem. Gut content analysis also exposed that, phytoplankton was the major food item constituting $94.38 \%$ of the gut contents' composition of $A$. mola whereas zooplankton comprised only $5.62 \%$. The results of this study conclude that, the $A$. mola is planktivorous in nature, feeding mostly on phytoplankton and could be a suitable species for integrated rice-fish farming.
\end{abstract}

Key words: Amblypharyngodon mola, Food and feeding habits, Gut contents, Rice-field ecosystem, Bangladesh.

\section{Introduction}

Rice and fish have been an indispensable part of the life of Bangladeshi people from time immemorial. Rice and fish are the staple foods of the Bangladeshi people. In Bangladesh, rice is the main agricultural crop with an annual production of over 29 million tons (BRKB, 2010), whereas annual fish production is 3.06 million tons per annum (FRSS, 2012). The demand for rice and fish is continuously increasing in the 
Md. Mostafizur Rahman Mondol, Dil Afroz Nahar, Somen Dewan, Md. Mosaddequr Rahman, Saleha Jasmine, and Md. Yeamin Hossain / Our Nature (2013) 11(1): 61-75

country with virtually three million people being added each year to the population of the country (Chowdhury, 2009). Nonetheless, integrated rice-fish farming offers a solution to this problem by contributing to food, income and nutrition. The total area of rice fields in Bangladesh is about 10.14 million ha with further 2.83 million ha of inundated seasonal rice fields where water remains for about 4-6 months (BRKB, 2010). The carrying capacities of these lands and waters are not fully utilized, thereby exists remarkable scope for increasing fish production through integrating aquaculture (Wahab et al., 2008). Integrated rice-fish production can optimize resource utilization through the complementary use of land and water (Frei and Becker, 2005). In addition, integration of fish with rice farming improves diversification, intensification, productivity, profitability, and sustainability (Ahmed et al., 2007; Nhan et al., 2007). It is now proved that integrated rice-fish farming is ecologically sound since fish improve soil fertility by increasing the availability of nitrogen and phosphorus (Giap et al., 2005; Dugan et al., 2006). On the other hand, rice fields provide fish with planktonic, periphytic and benthic food (Mustow, 2002). However, rice-fish farming remains marginal in Bangladesh mainly due to socioeconomic, environmental, technological, and institutional restraints (Nabi, 2008). Nonetheless, some of the small fishes are presently being cultured in the rice fields along with rice. A. mola is one of the indigenous small fishes that are now getting popularity in rice-fish farming.

The Mola carplet, Amblypharyngodon mola is an indigenous small fish species widely distributed in the rivers, canals, haors, baors, lakes, ponds, beels, floodplains, slow moving streams, and paddy fields of Bangladesh, India, Myanmar, and Pakistan (Talwar and Jhingran, 1991) and is also reported from Afghanistan (Coad, 1981). The Mola carplet is a popular food fish in Indian subcontinent because of its good taste and high nutritive value (Saha and Hossain, 2009). Nevertheless, the potential threats to this species are yet to be identified and therefore the Mola carplet is categorized as least concerned by IUCN (Chaudhry, 2010).

However, for efficient rice-fish farm management as well as optimum fish production from a certain environment, it is prerequisite to know the food and feeding habits of the selected fish species for interspecific relationships. Though a few studies on the food and feeding habits of the Mola carplet from different water bodies are available in the literature (Mamun et al., 2004; Gupta and Banerjee, 2013), reports from rice-fish farming are evidently lacking. Therefore, the objectives of the present study were to investigate the food and feeding habits of $A$. mola in the rice-fish ecosystem in Mymensingh, Bangladesh.

\section{Materials and methods}

Experimental design and land preparation The present study was conducted in the Agronomy field laboratory, Bangladesh Agricultural University, Mymensingh $\left(24^{\circ} 75^{\prime} \mathrm{N}, 90^{\circ} 50^{\prime} \mathrm{E}\right)$, Bangladesh from May 1999 to August 1999. The experimental site was selected in a relatively low land area within the deep tube-well irrigation facilities and consists of 2 experimental plots each with an area of 0.02 ha. Small water channels $\left(0.70 \times 0.30 \mathrm{~m}^{2}\right)$ were made between the plots to ensure water supply to 
Md. Mostafizur Rahman Mondol, Dil Afroz Nahar, Somen Dewan, Md. Mosaddequr Rahman, Saleha Jasmine, and Md. Yeamin Hossain / Our Nature (2013) 11(1): 61-75

the plots from deep tube-well. A $0.70 \mathrm{~m}$ high and $0.50 \mathrm{~m}$ wide embankment encircling the experimental plots were made to keep the plots free from flood during heavy rainfall. In addition, one common inlet and outlet was provided on the dykes of each plot to regulate water depth and bamboo poles were placed to prevent invasion of wild fish and escape of stocked fish. The land was ploughed properly with power tiller and country plough and then leveled properly by laddering to keep even water depth throughout the plots. To provide refuge to the stocked fish during high water temperature and low water level, a small ditch and a trench connecting the ditch were constructed in each plot. The area of each ditch was $4 \mathrm{~m}^{2}$ with a depth of about $70 \mathrm{~cm}$. The width and depth of the trenches were $40 \mathrm{~cm}$ and $30 \mathrm{~cm}$, respectively which were almost similar to the commonly practiced rice-fish farming in Indonesia (De la Cruz, 1992) and Bangladesh (Mazid et al., 1992).

\section{Fertilization}

The rice plots were fertilized with urea, triple super phosphate (TSP), muriate of potash (MP) and gypsum at the rate of 200 $\mathrm{kg} / \mathrm{ha}, 150 \mathrm{~kg} / \mathrm{ha}, 75 \mathrm{~kg} / \mathrm{ha}$ and $166 \mathrm{~kg} / \mathrm{ha}$, respectively. All inorganic fertilizers except urea were applied evenly to the plots 2-3 days before transplanting the rice seedlings during the final ploughing and leveling. Whereas urea was applied after 15, 55 and 70 days of transplanting rice seedlings with one third of total dose during each application.

\section{Transplantation of rice seedlings}

The high yielding variety of rice BR-2 having resistant power to insects and diseases was selected for this experiment. The rice seedlings were raised in a separate seedbed near the experimental plots. Forty days old seedlings were uprooted carefully for transplantation in the experimental plots. Then the rice seedlings were transplanted on 18 May 1999 in alternate rows with spacing of $35 \mathrm{~cm}+15 \mathrm{~cm}$ according to Hossain et al. (1990).

\section{Stocking of fish fingerlings}

Fingerlings of $A$. mola were stocked in the rice plots 20 days after transplantation of rice seedlings. In both the plots, fingerlings of A. mola were stocked at a rate of $20,000 /$ ha. The mean initial length and weight of the fishes were recorded at the time of stocking. For maintaining suitable water depth in the rice fields for fish water was supplied regularly from the deep tubewell. During the study period no supplementary feed was given to the fish.

\section{Monitoring of water quality parameters}

During the study period water temperature was recorded with a Celsius thermometer. Dissolved oxygen (DO) and $\mathrm{pH}$ were measured directly by using a digital electronic oxygen meter (YSI, Model 58) and $\mathrm{pH}$ meter (Jenway, Model - 3020), respectively. Total alkalinity was determined using methyl orange indicator and standard EDTA solution by titrimetric method. These parameters were recorded weekly and the average values were noted each month. The concentration of nitratenitrogen $(\mathrm{mg} / 1)$ and phosphate-phosphorus $(\mathrm{mg} / \mathrm{l})$ of water samples were determined in laboratory after filtering the water samples taken from each rice plot by using a spectrophotometer (Hack DR - 2000) and reagent pillow nitrover and phosver-3. 
Md. Mostafizur Rahman Mondol, Dil Afroz Nahar, Somen Dewan, Md. Mosaddequr Rahman, Saleha Jasmine, and Md. Yeamin Hossain / Our Nature (2013) 11(1): 61-75

Chlorophyll $a(\mu \mathrm{g} / \mathrm{l})$ was measured from the filter paper (Whatman $\mathrm{GF} / \mathrm{C}$ ) used for filtering the water samples. The filter paper was dissolved in $10 \mathrm{ml}$ acetone and made ready for the analysis of chlorophyll $a$. Later chlorophyll $a$ was determined by using a spectrophotometer (Milton and Roy Spectronic, Model - 1001) at 664 and 750 $\mathrm{nm}$ wavelengths. These parameters were recorded fortnightly and then average values were noted for each month.

\section{Plankton study from the water sample}

Ten liters of water sample were collected fortnightly from different areas and depth of the water of the rice plots and passed through fine meshed $(25 \mu \mathrm{m})$ plankton net. Filtered samples were taken in a measuring cylinder and carefully made up to a standard volume of $50 \mathrm{ml}$. Then the collected plankton samples were preserved in 5\% buffered formalin solution in small plastic vials for subsequent studies. From each 50 $\mathrm{ml}$ preserved sample, $1 \mathrm{ml}$ sub-sample was examined using a Sedge-wick-Rafter cell (S-R-cell) under a binocular microscope (Olympus, Model B-2, with phase contrast facilities). The counting chamber of the S$\mathrm{R}$-cell is equally divided into 1000 fields each having a volume of $0.001 \mathrm{ml}$. Ten square fields of the S-R-cell chosen randomly and all planktonic organisms of these fields were counted and expressed numerically as per liter of water. Calculation of plankton samples was done by using the formula of Stirling (1985) as $\mathrm{N}$ $=(\mathrm{A} \times 1000 \times \mathrm{C}) /(\mathrm{V} \times \mathrm{F} \times \mathrm{L})$, where, $\mathrm{N}$ is the number of plankton cells or units per liter of original water, $\mathrm{A}$ is the total number of plankton counted, $\mathrm{C}$ is the volume of final concentrate of the samples in $\mathrm{ml}, \mathrm{V}$ is the volume of field in cubic $\mathrm{ml}, \mathrm{F}$ is the number of fields counted and $\mathrm{L}$ is the volume of original water in liter.

\section{Plankton study from the gut contents of $A$. mola}

Thirty fishes were sampled fortnightly from the plots during study to determine the food and feeding habits. Immediately after sampling the fishes were preserved in $10 \%$ formalin solution. At first the length of the individual fish was recorded in $\mathrm{cm}$. Then the stomach of each fish was dissected out and the contents of it were removed very carefully on Petridish. Only the anterior portion of the digestive tract lying between the oesophagus and the first major curve of the small intestine of entire gut was taken for this investigation (McComish, 1967; McKehni and Penner, 1971; Dewan, 1973). Food contents of the gut were diluted in 5 $\mathrm{ml}$ distilled water. $1 \mathrm{ml}$ sub-sample was transferred by a pipette to an S-R-cell. Ten fields out of 1000 fields of the counting cell were counted and multiplied by 500 to get the total number of plankton in the gut. By using a binocular microscope all organisms were counted and identified up to genus level. Then the occurrence of each and every food item in the individual gut was recorded. The gut contents were analyzed using the following methods:

i. Occurrence method (Hynes, 1950): where the number of fish in which each food item occurred was listed as percentage of the total number of fish examined.

ii. Numerical method (Hynes, 1950): where the number of individuals of each food item were recorded and expressed as percentage of the total number of organisms found in all the fish examined. 
Md. Mostafizur Rahman Mondol, Dil Afroz Nahar, Somen Dewan, Md. Mosaddequr Rahman, Saleha Jasmine, and Md. Yeamin Hossain / Our Nature (2013) 11(1): 61-75

\section{Results}

Water quality parameters in rice field

Monthly values of the water quality parameters including water temperature, dissolved oxygen (DO), $\mathrm{pH}$, total alkalinity, chlorophyll $a$, nitrate-nitrogen and phosphate-phosphorus are given in table 1. The water temperature ranged from $27.33^{\circ}$ to $29.40^{\circ} \mathrm{C}$, dissolved oxygen from 4.01 $\mathrm{mg} / 1$ to $4.40 \mathrm{mg} / 1$, $\mathrm{pH}$ from 6.26 to 7.31 , total alkalinity from $34 \mathrm{mg} / 1$ to $90 \mathrm{mg} / 1$, chlorophyll $a$ from $11.73 \mu \mathrm{g} / 1$ to 22.73 $\mu \mathrm{g} / 1$, nitrate-nitrogen from $2.05 \mathrm{mg} / 1$ to $3.16 \mathrm{mg} / 1$ and phosphate-phosphorus contents from $0.17 \mathrm{mg} / 1$ to $0.90 \mathrm{mg} / 1$ during the study period.

\section{Plankton population in the water of rice plots}

The plankton populations in the water of rice fields were identified and enumerated up to genus level (Tab. 2). The phytoplankton populations recorded were divided into 4 broad groups viz, Chlorophyceae, Euglenophyceae, Cyanophyceae and Bacillariophyceae. Out of 37 genera of phytoplankton recorded during the study, 19 were belonged to Chlorophyceae, 2 to Euglenophyceae, 10 to Cyanophyceae and 6 to Bacillariophyceae. In addition, a total of 11 genera of zooplankton were recorded in the rice field under the groups Rotifera, Cladocera and Copepoda (Tab. 2).

Among the phytoplankton populations, Chlorophyceae was found to be the most dominant phytoplankton group $\left(8.5 \times 10^{3}\right.$ cells $/ 1$ and $38.23 \%$ out of all the plankton) followed by Bacillariophyceae and Euglenophyceae. Consequently, Rotifera was found to be the most dominant group of zooplankton $\left(3.5 \times 10^{3}\right.$ cells $/ 1$ in number and $15.63 \%$ out of all the plankton) followed by Copepoda and Cladocera (Tab. $3)$.

\section{Generic abundance of phytoplankton population in the water of rice plots}

In the water of the rice plots, the dominant genera of phytoplankton recorded were Chlorella (3.22\%), Scenedesmus (2.98\%), Ceratium (2.73\%), Cosmarium (2.73\%), Oocystis (2.73\%) and Chrysococcus (2.49\%) under Chlorophyceae, Euglena (2.98\%) under Euglenophyceae, Oscillatoria $(1.73 \%)$, Gloeocapsa $(1.73 \%)$ and Nostoc $(1.73 \%)$ under Cyanophyceae, Navicula (3.98\%) and Fragilaria (3.72\%) under Bacillariophyceae. In contrast, the least dominant genera of phytoplankton were Oedogonium (1.07\%), Tetraodon (1.24\%), Pediastrum (1.24\%) and Actinastrum (1.24\%) under Chlorophyceae, Phacus (1.98\%) under Euglenophyceae, Anabaena (1.00\%), and Aphanocapsa $(1.00 \%)$ under Cyanophyceae, Melosira $(1.49 \%)$, Tabellaria $(1.73 \%)$ and Actinella $(1.73 \%)$ under Bacillariophyceae. The dominant genera in zooplankton population were Brachionus (3.23\%) and Polyartha $(2.98 \%)$ under Rotifera, Diaphanosoma $(2.73 \%)$ under Cladocera and Nauplius (3.23\%) and Cyclops (2.98\%) under Copepoda. On the other hand, the least dominant genera of zooplankton were Keratella (1.735\%) and Trichocerca (2.23\%) under in Rotifera, Daphnia $(1.73 \%)$ under Cladocera and Diaptomus (1.49\%) under Copepoda (Tab. 3).

\section{Plankton population in the gut contents of A. mola}

The phytoplankton population recorded in the gut contents of $A$. mola was also divided into 4 groups viz., Chlorophyceae, Eugleno- 
Md. Mostafizur Rahman Mondol, Dil Afroz Nahar, Somen Dewan, Md. Mosaddequr Rahman, Saleha Jasmine, and Md. Yeamin Hossain / Our Nature (2013) 11(1): 61-75

phyceae, Cyanophyceae and Bacillariophyceae (Tab. 4). The total number of phytoplankton genera recorded in the gut contents of A. mola was 32 of which 17 were under Chlorophyceae, 2 under Euglenophyceae, 7 under Cyanophyceae and 6 under Bacillariophyceae (Tab. 4). Among the 4 groups of phytoplankton Chlorophyceae was the most dominant group in the gut contents of $A$. mola both by percentage in number $(45.12 \%)$ and percentage of frequency of occurrence $(100 \%)$, which was closely followed by Bacillariophyceae $(34.10 \%$ in number and $100 \%$ in occurrence) (Tab. 5, Figs. 1 and 2). Among all the food groups Euglenophyceae was found to be the least dominant food group.

On the other hand, the zooplankton population recorded in the gut contents of $A$. mola was divided into 3 groups viz., Rotifera, Cladocera and Copepoda. A total of 8 genera of zooplankton were recorded in the gut contents of $A$. mola. Out of 8 genera, 3 were under Rotifera, 2 under Cladocera and 3 under Copepoda. Cladocera was the most dominant zooplankton group in the gut contents of $A$. mola $(2.04 \%$ in number and $43 \%$ in occurrence) which was closely followed by Rotifera and Copepoda (Tab. 5 , Figs. 1 and 2).

\section{Generic abundance of plankton population in the gut contents of A. mola}

The generic abundance of plankton population in the gut contents were determined by percentage of frequency of occurrence and percentage in number are presented in the table 6. Among all the genera of phytoplankton Navicula was found to be the most dominant genus $(22.59 \%$ in number and
$91.42 \%$ by occurrence) followed by Chlorella, Closterium, Fragilaria, Chrysococcus, Oscillatoria, Gomphosphaeria, $\mathrm{Ce}$ ratium, Ulothrix, Scnedesmus and Ankistrodesmus. Among zooplankton Diaphanosoma was found to be the most dominant genera, which contributed $25.71 \%$ by percentage of frequency of occurrence and $1.10 \%$ by percentage in number (Tab. 6 ).

Relative abundance of food item in the gut contents of $A$. mola in relation to their availability in the water of rice fields

The relative abundance of different food item in the gut contents of $A$. mola in relation to their availability in the water of rice fields was determined by percentage in number (Tabs. 3 and 6). Among different genera of phytoplankton Navicula, Fragilaria, Chlorella, Chrysococcus, Closterium, Oscillatoria and Gompho-sphaeria were found abundant both in the water of the rice field and in the gut contents of $A$. mola, indicating that, these genera are preferred food of this fish. Though the genera such as Gonatogygm, Oocystis, Aphanocapsa and Nostoc were found abundantly in the water of the rice fields but they were not recorded in the gut content of the fish indicating their absence in the preference list of food of $A$. mola.

On the other hand, among the zooplankton, Cyclops, Diaphanosoma, Keratella and Polyarthra were found to occur more or less abundantly both in the gut contents of fish as well as in the water of rice plots which point out that, these genera are preferred by the Mola carplet. However, Asplanchna and Filinia recorded abundantly in the water of rice field but were absent in the gut contents. 
Md. Mostafizur Rahman Mondol, Dil Afroz Nahar, Somen Dewan, Md. Mosaddequr Rahman, Saleha Jasmine, and Md. Yeamin Hossain / Our Nature (2013) 11(1): 61-75

Table 1. Monthly variation (mean $\pm \mathrm{SD}$ ) of water quality parameters recorded during the study period in the rice plots, Mymensingh, central Bangladesh.

\begin{tabular}{lcccc}
\hline \multirow{2}{*}{ Parameters } & \multicolumn{3}{c}{ Monthly average values } & \multirow{2}{*}{ Range } \\
\cline { 2 - 4 } & June & July & August & $27.33-29.40$ \\
Water temperature $\left({ }^{\circ} \mathrm{C}\right)$ & $28.03 \pm 0.07$ & $28.37 \pm 0.47$ & $27.80 \pm 0.18$ & $4.01-4.40$ \\
Dissolved oxygen $(\mathrm{mg} / \mathrm{l})$ & $4.11 \pm 0.06$ & $4.28 \pm 0.09$ & $4.09 \pm 0.07$ & $6.26-7.31$ \\
$\mathrm{pH}$ & $6.68 \pm 0.03$ & $6.94 \pm 0.27$ & $6.56 \pm 0.34$ & $34.0-90.0$ \\
Total alkalinity $(\mathrm{mg} / \mathrm{l})$ & $42.00 \pm 3.30$ & $40.50 \pm 4.11$ & $70.00 \pm 8.27$ & $11.73-22.73$ \\
Chlorophyll $a(\mu \mathrm{g} / \mathrm{l})$ & $14.86 \pm 0.70$ & $15.40 \pm 0.11$ & $17.74 \pm 0.83$ & $2.05-3.16$ \\
Nitrate-nitrogen $(\mathrm{mg} / \mathrm{l})$ & $2.10 \pm 0.08$ & $2.65 \pm 0.05$ & $2.28 \pm 0.20$ & $0.17-0.90$ \\
Phosphate-phosphorus $(\mathrm{mg} / \mathrm{l})$ & $0.74 \pm 0.06$ & $0.73 \pm 0.15$ & $0.44 \pm 0.05$ & \\
\hline
\end{tabular}

Table 2. List of genera of phytoplankton and zooplankton recorded during the study period in the rice plots, Mymensingh, central Bangladesh

\begin{tabular}{llc}
\hline Food groups & Genera & Total \\
\hline $\begin{array}{c}\text { Phytoplankton } \\
\text { Chlorophyceae }\end{array}$ & $\begin{array}{l}\text { Actinastrum, Ankistrodesmus, Botryococcus, Ceratium, Chlorella, } \\
\text { Chrysococcus, Closterium, Coelastrum, Cosmarium, Gonatozygon }\end{array}$ \\
& Oocystis, Scenedesmus, Pediastrum, Spirogyra, Tetraodon, Volvox \\
& Zygnema, Oedogonium, Ulothrix \\
Euglenophyceae & Euglena, Phacus \\
Cyanophyceae & Anabaena, Aphanocapsa, Gloeotrichia, Gomphosphaeria, Nostoc, \\
& Merismopedia, Gloeocapsa, Microcystis, Oscillatoria, Aphanizomenon \\
Bacillariophyceae & Cyclotella, Fragilaria, Melosira, Actinella, Navicula, Tabellaria \\
Total Phytoplankton & & 19 \\
\hline Zooplankton & & 6 \\
Rotifera & Asplanchna, Brachionus, Filinia, Keratella, Polyarthra, Trichocerca \\
Cladocera & Daphnia, Diaphanosoma \\
Copepoda & Cyclops, Diaptomus, Nauplius \\
Total Zooplankton & & $\mathbf{3 7}$ \\
\hline
\end{tabular}

Table 3. Composition of different food items recorded during the study period in the rice plots, Mymensingh, central Bangladesh.

\begin{tabular}{llcc}
\hline Food items & & Average in number & Percentage in number \\
\hline Phytoplankton & & \\
Chlorophyceae & Actinastrum & 277.77 & 1.24 \\
& Ankistrodesmus & 388.77 & 1.73 \\
Botryococcus & 333.33 & 1.49 \\
Ceratium & 611.11 & 2.73 \\
& Chlorella & 722.22 & 3.22 \\
Chrysococcus & 555.55 & 2.49 \\
Closterium & 500.00 & 2.23 \\
& Coelastrum & 444.44 & 1.99 \\
Cosmarium & 611.11 & 2.73 \\
& Gonatogygon & 444.44 & 1.99 \\
& Oocystis & 611.11 & 2.73 \\
& Scenedesmus & 666.66 & 2.98 \\
\hline
\end{tabular}


Md. Mostafizur Rahman Mondol, Dil Afroz Nahar, Somen Dewan, Md. Mosaddequr Rahman, Saleha Jasmine, and Md. Yeamin Hossain / Our Nature (2013) 11(1): 61-75

\begin{tabular}{|c|c|c|c|}
\hline & Pediastrum & 277.77 & 1.24 \\
\hline & Spirogyra & 444.44 & 1.99 \\
\hline & Tetraodon & 277.77 & 1.24 \\
\hline & Volvox & 333.33 & 1.49 \\
\hline & Zygnema & 333.33 & 1.49 \\
\hline & Oedogonium & 222.22 & 1.00 \\
\hline & Ulothrix & 500.00 & 2.23 \\
\hline & Total & 8555.37 & 38.23 \\
\hline \multirow[t]{3}{*}{ Euglenophyceae } & Euglena & 666.66 & 2.98 \\
\hline & Phacus & 444.44 & 1.98 \\
\hline & Total & 1111.11 & 4.96 \\
\hline \multirow{11}{*}{ Cyanophyceae } & Anabaena & 222.22 & 1.00 \\
\hline & Aphanocapsa & 333.33 & 1.48 \\
\hline & Gloeotrichia & 277.78 & 1.24 \\
\hline & Gomphosphaeria & 333.33 & 1.48 \\
\hline & Merismopedia & 222.22 & 1.00 \\
\hline & Gloeocapsa & 388.88 & 1.73 \\
\hline & Microcystis & 333.33 & 1.49 \\
\hline & Oscillatoria & 388.88 & 1.73 \\
\hline & Aphanizomenon & 222.22 & 1.00 \\
\hline & Nostoc & 388.88 & 1.73 \\
\hline & Total & 3111.07 & 13.88 \\
\hline \multirow[t]{7}{*}{ Bacillariophyceae } & Cyclotella & 555.55 & 2.49 \\
\hline & Fragilaria & 833.33 & 3.72 \\
\hline & Melosira & 333.33 & 1.49 \\
\hline & Actinella & 388.88 & 1.73 \\
\hline & Navicula & 888.88 & 3.98 \\
\hline & Tabellaria & 388.88 & 1.73 \\
\hline & Total & 3388.85 & 15.14 \\
\hline \multicolumn{2}{|c|}{ Total Phytoplankton } & 16166.39 & 72.21 \\
\hline \multicolumn{4}{|c|}{ Zooplankton } \\
\hline \multirow[t]{7}{*}{ Rotifera } & Asplanchna & 611.11 & 2.73 \\
\hline & Brachionus & 722.22 & 3.23 \\
\hline & Filinia & 611.11 & 2.73 \\
\hline & Keratella & 388.88 & 1.73 \\
\hline & Polyarthra & 666.66 & 2.98 \\
\hline & Trichocerca & 500.00 & 2.23 \\
\hline & Total & 3500.00 & 15.63 \\
\hline \multirow[t]{3}{*}{ Cladocera } & Daphnia & 388.88 & 1.73 \\
\hline & Diaphanosoma & 611.11 & 2.73 \\
\hline & Total & 999.99 & 4.46 \\
\hline \multirow{4}{*}{ Copepoda } & Cyclops & 666.66 & 2.98 \\
\hline & Diaptomus & 333.33 & 1.49 \\
\hline & Nauplius & 722.22 & 3.23 \\
\hline & Total & 1722.21 & 7.70 \\
\hline \multicolumn{2}{|l|}{ Total Zooplankton } & 6222.20 & 27.79 \\
\hline
\end{tabular}


Md. Mostafizur Rahman Mondol, Dil Afroz Nahar, Somen Dewan, Md. Mosaddequr Rahman, Saleha Jasmine, and Md. Yeamin Hossain / Our Nature (2013) 11(1): 61-75

Table 4. Generic status of different phytoplankton and zooplankton in the gut contents of $A$. mola recorded during the study period in the rice plots, Mymensingh, central Bangladesh.

\begin{tabular}{|c|c|c|}
\hline Food groups & Genera & Total \\
\hline \multicolumn{3}{|l|}{ Phytoplankton } \\
\hline \multirow[t]{4}{*}{ Chlorophyceae } & Actinastrum, Ankistrodesmus, Botryococcus, Ceratium, Chlorella, & \\
\hline & Chrysococcus, Closterium, Coelastrum, Cosmarium, & \\
\hline & Scenedesmus, Pediastrum, Spirogyra, Tetraodon, Volvox, & \\
\hline & Zygnema, Oedogonium, Ulothrix & 17 \\
\hline Euglenophyceae & Euglena, Phacus & 2 \\
\hline \multirow[t]{2}{*}{ Cyanophyceae } & Anabaena, Gloeotrichia, Gomphosphaeria, Microcystis, & \\
\hline & Merismopedia, Oscillatoria, Aphanizomenon & 7 \\
\hline \multirow[t]{2}{*}{ Bacillariophyceae } & Cyclotella, Fragilaria, Frustularia, Navicula, Nitzschia, & \\
\hline & Tabellaria, & 6 \\
\hline Total phytoplankton & & 32 \\
\hline \multicolumn{3}{|l|}{ Zooplankton } \\
\hline Rotifera & Brachionus, Keratella, Polyarthra & 3 \\
\hline Cladocera & Daphnia, Diaphanosoma & 2 \\
\hline Copepoda & Cyclops, Diaptomus, Nauplius & 3 \\
\hline Total Zooplankton & & 8 \\
\hline
\end{tabular}

Table 5. Composition of different food groups in the gut content of $A$. mola by percentage in number and percentage of frequency of occurrence recorded during the study period in the rice plots, Mymensingh, central Bangladesh.

\begin{tabular}{lcc}
\hline Food groups & Percentage in number & Percentage in occurrence \\
\hline Phytoplankton & & \\
Chlorophyceae & 45.12 & 100.00 \\
Euglenophyceae & 0.95 & 23.00 \\
Cyanophyceae & 14.21 & 83.00 \\
Bacillariophyceae & 34.1 & 100.00 \\
Total Phytoplankton & 94.38 & \\
\hline Zooplankton & & \\
Rotifera & 1.84 & 46.00 \\
Cladocera & 2.04 & 46.00 \\
Copepoda & 1.74 & 34.00 \\
Total Zooplankton & 5.62 & \\
\hline
\end{tabular}

Table 6: Composition of different food items in the gut contents of $A$. mola by percentage in number and percentage of frequency of occurrence recorded during the study period in the rice plots, Mymensingh, central Bangladesh.

\begin{tabular}{llcc}
\hline Food items & & Percentage in number & Percentage in occurrence \\
\hline Phytoplankton & & \\
Chlorophyceae & Actinastrum & 0.15 & 2.85 \\
& Ankistrodesmus & 2.27 & 37.14 \\
& Botryococcus & 0.15 & 22.86 \\
& Ceratium & 2.86 & 37.14 \\
& Chlorella & 11.65 & 85.71 \\
& Chrysococcu & 7.11 & 60.00 \\
\hline
\end{tabular}


Md. Mostafizur Rahman Mondol, Dil Afroz Nahar, Somen Dewan, Md. Mosaddequr Rahman, Saleha Jasmine, and Md. Yeamin Hossain / Our Nature (2013) 11(1): 61-75

\begin{tabular}{|c|c|c|c|}
\hline & Closterium & 10.62 & 80.57 \\
\hline & Coelastrum & 1.17 & 17.14 \\
\hline & Cosmarium & 0.15 & 2.85 \\
\hline & Scenedesmus & 2.27 & 34.29 \\
\hline & Pediastrum & 1.68 & 22.86 \\
\hline & Spirogyra & 0.81 & 11.42 \\
\hline & Tetraodon & 0.45 & 2.85 \\
\hline & Volvox & 0.39 & 5.71 \\
\hline & Zygnema & 0.37 & 14.29 \\
\hline & Oedogonium & 0.15 & 2.85 \\
\hline & Ulothrix & 2.86 & 35.43 \\
\hline & Total & 45.12 & \\
\hline Euglenophyceae & Euglena & 0.51 & 14.29 \\
\hline & Phacus & 0.44 & 5.71 \\
\hline & Total & 0.95 & \\
\hline Cyanophyceae & Anabaena & 2.12 & 28.57 \\
\hline & Gloeotrichia & 0.73 & 17.14 \\
\hline & Gomphosphaeria & 3.74 & 40.00 \\
\hline & Merismopedia & 1.10 & 8.57 \\
\hline & Microcystis & 0.73 & 11.43 \\
\hline & Oscillatoria & 5.43 & 57.14 \\
\hline & Aphanizomenon & 0.36 & 5.71 \\
\hline & Total & 14.21 & \\
\hline Bacillariophyceae & Cyclotella & 0.29 & 5.71 \\
\hline & Fragilaria & 9.39 & 74.29 \\
\hline & Frustularia & 0.22 & 5.71 \\
\hline & Navicula & 22.59 & 91.42 \\
\hline & Tabellaria & 1.54 & 17.14 \\
\hline & Nitzschia & 0.07 & 2.86 \\
\hline & Total & 34.10 & \\
\hline Total Phytoplankt & & 94.38 & \\
\hline Zooplankton & & & \\
\hline Rotifera & Brachionus & 0.51 & 14.29 \\
\hline & Keratella & 0.66 & 14.29 \\
\hline & Polyarthra & 0.67 & 17.14 \\
\hline & Total & 1.84 & \\
\hline Cladocera & Daphnia & 0.94 & 17.14 \\
\hline & Diaphanosoma & 1.10 & 25.71 \\
\hline & Total & 2.04 & \\
\hline Copepoda & Cyclops & 1.02 & 22.86 \\
\hline & Diaptomus & 0.44 & 8.57 \\
\hline & Nauplius & 0.28 & 5.71 \\
\hline & Total & 1.74 & \\
\hline Total zooplankton & & 5.62 & \\
\hline
\end{tabular}


Md. Mostafizur Rahman Mondol, Dil Afroz Nahar, Somen Dewan, Md. Mosaddequr Rahman, Saleha Jasmine, and Md. Yeamin Hossain / Our Nature (2013) 11(1): 61-75

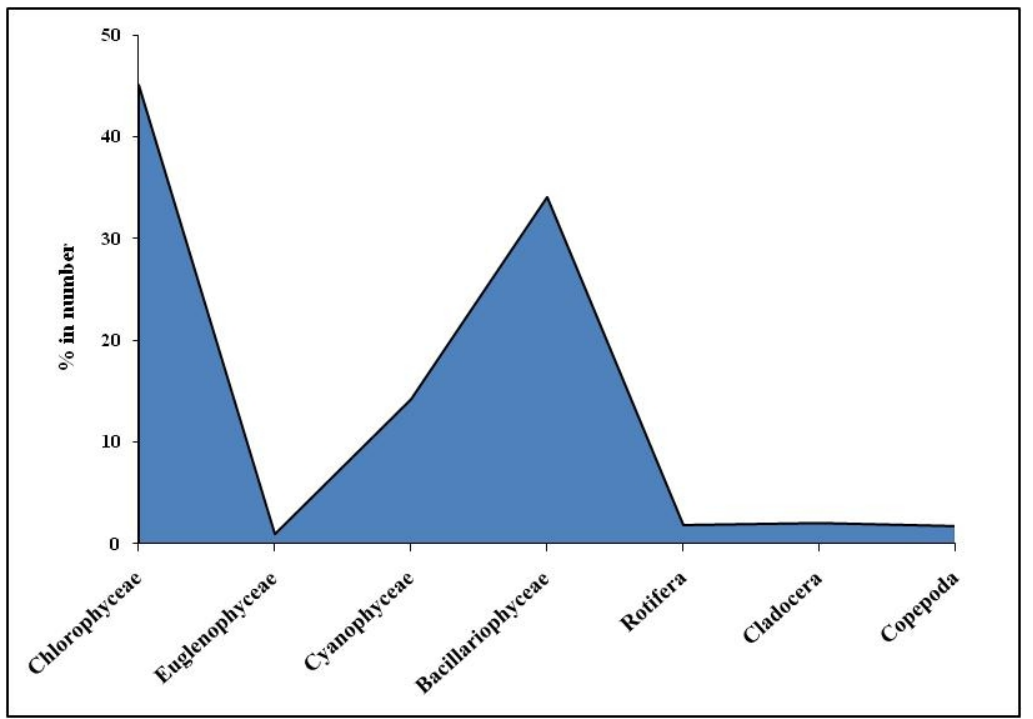

Figure 1. Composition (\% in number) of different food groups found in the gut contents of $A$. mola recorded during the study period in the rice plots, Mymensingh, central Bangladesh.

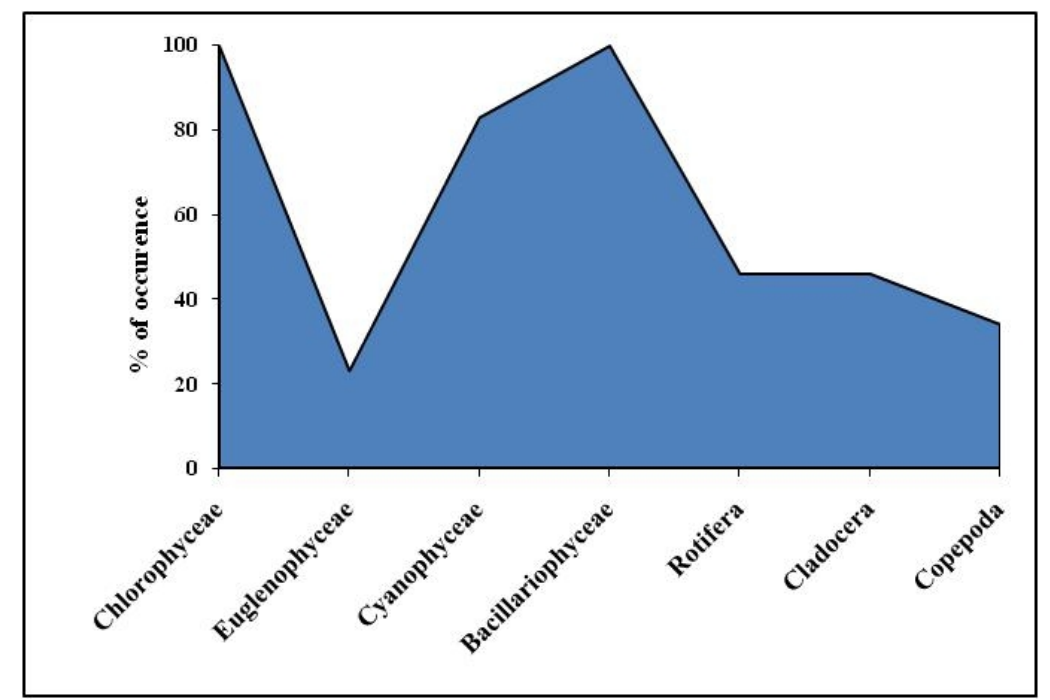

Figure 2. Percentage of occurrence of different plankton groups in the gut content of $A$. mola recorded during the study period in the rice plots, Mymensingh, central Bangladesh.

\section{Discussion}

\section{Water quality parameters}

The water quality parameters were recorded during the study period was found within the acceptable ranges. Among the water quality parameters, water temperature is an important factor that influences the physicochemical and biological properties of water body. In the present study, water temperature was found to lie between 
Md. Mostafizur Rahman Mondol, Dil Afroz Nahar, Somen Dewan, Md. Mosaddequr Rahman, Saleha Jasmine, and Md. Yeamin Hossain / Our Nature (2013) 11(1): 61-75

$27.33^{\circ}$ to $29.40^{\circ} \mathrm{C}$ which are in accordance to those reported by Ali (1990) and Ghosh (1992).

Dissolved oxygen is the most critical chemical factor in water especially in rice fields. The values of dissolved oxygen were found to vary between $4.01 \mathrm{mg} / 1$ to 4.40 $\mathrm{mg} / 1$. This finding is more or less similar to the findings of Ghosh (1992) and Uddin (1998). Additionally, in both the plots, the values of $\mathrm{pH}$ were slightly alkaline, ranged from 6.26 to 7.31 , which is very close to the value of 7.3 obtained by Uddin (1998) in his experiment in rice-fish culture.

The concentration of chlorophyll $a$ ranged from $11.73 \mu \mathrm{g} / 1$ to $22.73 \mu \mathrm{g} / 1$ during the present study. Values obtained during present study were within the range of $14.70 \mu \mathrm{g} / 1$ to $55.0 \mu \mathrm{g} / 1$ reported by Uddin (1998). However, the value of chlorophyll $a(45.2 \mu \mathrm{g} / 1)$ reported by Ali (1990) in rice fields was much higher than the values obtained in the present study. Nonetheless, the values of chlorophyll $a$ showed wide variations during the period of study, which might be associated with the grazing pressure of fishes as well as water level fluctuation within the study plots due to heavy rainfall.

The values of Nitrate-Nitrogen $\left(\mathrm{NO}_{3}\right.$ $\mathrm{N})$ in the water of rice fields fluctuated between $2.05 \mathrm{mg} / 1$ and $3.16 \mathrm{mg} / 1$ during the study indicating that the water of the study plots was highly productive (Alikunhi, 1957). However, the nitrate level $(0.02 \mathrm{mg} / 1$ to $2.6 \mathrm{mg} / 1)$ reported by Ghosh (1992) is almost similar to the values obtained in the present study. Whereas the range reported by Ali (1990) $(0.22 \mathrm{mg} / 1$ to $2.30 \mathrm{mg} / 1)$ and Whitton et al. (1988) (0.006 $\mathrm{mg} / 1$ to $0.05 \mathrm{mg} / 1$ ) in the water of rice fields were far less than the values of the present study. The higher values found in the present study may be due to the application of TSP in the rice plots.

\section{Plankton population in the water of rice plots}

The phytoplankton population recorded in the present study was grouped as Chlorophyceae, Euglenophyceae, Cyanophyceae and Bacillariophyceae and zooplankton population as Rotifera, Cladocera and Copepoda. In this study a total of 37 genera of phytoplankton and 11 genera zooplankton were documented. Dewan et al. (1991) identified 27 genera of phytoplankton belonging to Chlorophyceae, Cyanophyceae, Bacillariophyceae and Euglenophyceae and 9 genera of zooplankton belonging to Hydrozoa, Rotifera and Crustacea in their study which closely match the findings of the present study.

Among 4 groups of phytoplankton Chlorophyceae was the most dominant group, which was closely followed by Bacillariophyceae and Euglenophyceae. Sah et al. (1971) also reported similar results. However, during the study, phytoplankton population was highly dominant over the zooplankton population. These findings are in accordance to the findings of Chowdury (1999).

\section{Plankton population in the gut contents of A. mola}

Gut content analysis revealed a sum of 32 genera of phytoplankton belonging to Chlorophyceae (17), Euglenophyceae (2), Cyanophyceae (7) and Bacillariophyceae (6) and 8 genera of zooplankton under Rotifera (3), Cladocera (2) and Copepoda (3). Likewise, Mamun et al. (2004) reported 25 genera of phytoplankton belonging to 
Md. Mostafizur Rahman Mondol, Dil Afroz Nahar, Somen Dewan, Md. Mosaddequr Rahman, Saleha Jasmine, and Md. Yeamin Hossain / Our Nature (2013) 11(1): 61-75

Chlorophyceae (13), Euglenophyceae (2), Cyanophyceae (5), Bacillariophyceae (5) and 6 genera of zooplankton belonging to Rotifera (4) and Crustacea (2) in the gut contents of the Mola carplet from the Kaptai Lake, Bangladesh.

Among the 4 groups of phytoplankton, Chlorophyceae was found to be the most dominant and preferred food group, which was followed by Bacillariophyceae, Cyanophyceae and Euglenophyceae. Furthermore, among all the genera of phytoplankton Navicula was the most preferred and dominant genus followed by Chlorella, Closterium, Fragilaria, Chrysococcus, Oscillatoria, Gomphosphaeria, Ceratium, Ulothrix, Scenedesmus and Ankistrodesmus. On the other hand, Diaphanosoma was the most preferred and dominant zooplankton. Overall, Navicula, Fragilaria, Chlorella, Chrysococcus, Closterium, Oscillatoria and Gomphosphaeria were found abundant both in the water of the rice plots and in the gut contents of $A$. mola indicating that, these genera are preferred food of this fish in the rice field ecosystem.

In another study on the food and feeding habits of $A$. mola in the wetland ecosystem of West Bengal India, Gupta and Benerjee (2013) categorized the gut materials into Chlorophyceae, Bacillariophyceae, Cyanophyceae, Euglenophyceae, Rotifera, planktonic Crustacean, plant parts and unidentified parts. According to the Index Preponderance value they reported Chlorophyceae as the most dominant and preferred food items of $A$. mola. Followed by Bacillariophyceae, Cyanophyceae, Euglenophyceae, Rotifera, Planktonic crustacean, unidentified parts and plant parts. Therefore, they conclude by stating A. mola as herbivorous fish, preferably feeding on
Chlorophyceae. Dewan (1973) and Chowdhury (1999) also recorded phytoplankton as the most dominant food group in the gut contents of A. mola. Accordingly, the results of this study also revealed that, phytoplankton is the most dominant food contributing $94.38 \%$ of the gut contents' composition of A. mola while zooplankton contributed only $5.62 \%$. The results of this study proved that $A$. mola is planktivorous fish, feeding mainly on phytoplankton and is a suitable species for integrated rice-fish farming.

\section{Acknowledgements}

We would like to express our acknowledgement to the Department of Fisheries Management, Faculty of Fisheries, Bangladesh Agricultural University, Bangladesh for laboratory facilities. Also, we express our gratitude to Global Fisheries Research Foundation (GFRF) for providing technical support during the preparation of this article.

\section{References}

Ahmed, N., M.A. Wahab and S.H. Thilsted 2007. Integrated aquaculture-agriculture systems in Bangladesh: potential for sustainable livelihoods and nutritional security of the rural poor. Aquaculture Asia 12(1): 14-22.

Ali, A.B. 1990. Rice fish farming in Malaysia: A resource optimization. AMBIO. 19: 404-408.

Alikunhi, K.H. 1957. Fish culture in India. Farm. Bull. India Council Agric. Res. 20: 144-144.

BRKB. 2010. Rice statistics in Bangladesh. Gazipur: Bangladesh Rice Knowledge Bank, Bangladesh Rice Research Institute.

Chaudhry, S. 2010. Amblypharyngodon mola. In IUCN Red List of Threatened Species. Version 2012. 2. <www.iucnredlist.org> Downloaded on 29 May 2013.

Chowdhury, F.A. 1999. Effects of Hypopthalmichthys molitrix and Catla catla on the growth, survival and yields of Amblypharylgodon mola in mixed 


\section{Md. Mostafizur Rahman Mondol, Dil Afroz Nahar, Somen Dewan, Md. Mosaddequr Rahman, Saleha Jasmine, and Md. Yeamin Hossain / Our Nature (2013) 11(1): 61-75}

culture. Bangladesh Agricultural University, Mymensingh. 131p. (M.Sc. Thesis)

Chowdhury, M.R. 2009. Population challenge facing Bangladesh. CW Post Campus, Long Island University, New York.

Coad, B.W. 1981. Fishes of Afghanistan, an annotated check-list. Zool. Natl. Mus. Can. 14: 23p.

De la Cruz, R.C. 1992. Rice-fish culture system in Indonesia. ICLARM and IRRI, Philippines. pp. 14.

Dewan, S. 1973. Investigations into the ecology of fishes of Mymensingh Lake. Bangladesh Agricultural University, Mymensingh Bangladesh. (Ph.D. Thesis)

Dewan, S., M.A. Wahab, M.C.M. Beveridge, M.H Rahman and B.K. Sarker 1991. Food selection, electivity and dietary overlap among planktivorous Chinese and Indian major carp fry and fingerlings grown in extensively managed, rainfed pond in Bangladesh. Aquacult. Fish. Manage. 22: 277-294.

Dugan, P., M.M. Dey and V.V. Sugunan 2006. Fisheries and water productivity in tropical river basins: enhancing food security and livelihoods by managing water for fish. Agricultural Water Management 80: 262-275.

Frei, M. and K. Becker 2005. Integrated rice-fish culture: coupled production saves resources. Natural Resources Forum 29: 135-143.

FRSS. 2012. Fisheries Statistical Yearbook of Bangladesh. Fisheries Resources Survey System (FRSS), Department of Fisheries, Bangladesh. Volume 28: 46p.

Ghosh, A. 1992. Rice-fish Farming Development in India: Past, Present and Future. In Rice-Fish Research and Development in Aisa (Eds. C.R. Dela-Cruz, C. Lightfoot, B.A. Costa-pierce, V.R. Carnagal, M.P. Bimbao.). The Marine Science Institute, Manila, Philippines. pp. 27-43.

Giap, D.H., Y. Yi and C.K. Lin 2005. Effects of different fertilization and feeding regimes on the production of integrated farming of rice and prawn Macrobrachium rosenbergii (De Man). Aquaculture Research 36: 292-299.

Gupta, S. and S. Banerjee 2013. Food and feeding habits of Amblypharyngodon mola (HamiltonBuchanan, 1822) in West Bengal India. International Research Journal of Biological Sciences 2(5): 67-71.

Hossain, A., A. Hussain, F.A. Chaughtai and M. Butt
1990. Effects of Leucana and Sesbania leaf manuring on crop growth and Physico-chemical properties of soil. Nitrogen Fix. Res. 43: 907-907.

Hynes, H.B.N. 1950. The food of freshwater stickle backs (Gasterosleus aculaetus and Pygosteus Pungitius), with a review of methods used in studied on the food of fishes. J. Anim. Ecol. 19: 36-48.

Mamun, A., K.M.A. Tareq and M.A. Azadi 2004. Food and feeding habits of Amblypharyngodon mola (Hamilton) from Kaptai reservoir, Bangladesh. Pakistan Journal of Biological Sciences 7(4): 584-588.

Mazid, M.A., B.C. Bakshi, A.K. Das and N. Bari 1992. Fish culture in rice field. FSRDP and BARC, Dhaka.

McComish, T.S. 1967. Food habits of big mouth and small buffalow in Lewis and Cark Lakes and Missouri River. Trans. Am. Fish. Soc. 69: 70-74.

McKehni, R.J. and R.B. Penner 1971. Food habits of white Sturgeons, Acipencer transmontanus in San Pablo and Suisan Bays Callifornia. California Fish Game 57: 109-212.

Mustow, S.E. 2002. The effects of shading on phytoplankton photosynthesis in rice-fish fields in Bangladesh. Agriculture, Ecosystems and Environment 90: 89-96.

Nabi, R. 2008. Constraints to the adoption of rice-fish farming by smallholders in Bangladesh: a farming systems analysis. Aquaculture Economics and Management 12: 145-153.

Nhan, D.K., L.T. Phong, M.J.C. Verdegem, L.T. Duong, R.H. Bosma and D.C. Little 2007. Integrated freshwater aquaculture, crop and livestock production in the Mekong delta, Vietnam: determinants and the role of the pond. Agricultural Systems 94: 445-458.

Sah, G.N., K.L. Sehgal, E. Mitra and A.C. Nandy 1971. Studies on the seasonal and diurnal variations in physico-chemical and biological parameters of a freshwater pond. J. Inland Fish Soc. India 3: 79-102.

Saha, A. and M.A. Hossain 2009. Reproductive biology of the Mola Carplet Amblypharyngodon mola (Hamilton) (Cypriniformes: Cyprinidae) from Netrakon water. Bangladesh Journal of Scientific \& Industrial Research 44(3): 377-379.

Stirling, H.P. 1985. Chemical and biological methods of water quality analysis for aquaculturists. Institute of aquaculture, university of Stirling, 
Md. Mostafizur Rahman Mondol, Dil Afroz Nahar, Somen Dewan, Md. Mosaddequr Rahman, Saleha Jasmine, and Md. Yeamin Hossain / Our Nature (2013) 11(1): 61-75

Scotland. 119p.

Talwar, P.K. and A.G. Jhingran 1991. Inland fishes of India and adjacent countries. Vols 1 and 2. Oxford and IBH Publishing Co. Pvt. Ltd. New Delhi, Bombay and Calcutta. 1063p.

Uddin, J.M. 1998. Effects of fish culture on rice fields of rice and nutrients availability in soil, straw and grain. Bangladesh Agricultural University Mymensingh. 115p. (M.Sc. Thesis)
Wahab, M.A., M. Kunda, M.E. Azim, S. Dewan and S.H. Thilsted 2008. Evaluation of freshwater prawn-small fish culture concurrently with rice in Bangladesh. Aquaculture Research 39: 15241532.

Whitton, B.A., A. Aziz, P. Francis, J.A. Rother, T.W. Simon and Z.N. Tahmida 1988. Ecology of deep water rice in Bangladesh (Physical and chemical environment). Hydrobiologia 169: 3-67. 